\title{
THE DEPENDENT, INDEPENDENT AND INTERDEPENDENT FUNCTIONS OF THE NURSE PRACTITIONER — A LEGAL AND ETHICAL PI PERSPECTIVE
}

\section{CHARLOTTE SEARLE}

\section{OPSOMMING}

Die funksies van die verpleegkundige kan beskou word as synde afhanklik, interafhanklik en onafhanklik. Die tradisionele beskouing van die betekenis van veral die afhanklike funksie word egter bevraagteken vanuit die wetlike en etiese perspektiewe wat in Suid-Afrika geld.

Omdat die verpleegkundige verantwoordelik en aanspreeklik is vir alles wat sy doen of laat is haar funksie slegs afhanklik van wat die Wet, wat haar praktyk rig, voorskryf.

Die interafhanklike funksie verwys na die interafhanklikheid tussen die verpleegkundige, die pasiënt en ander lede van die gesondheidspan. Die verpleegkundige en die geneesheer is mede-verantwoordelik vir die welsyn van die pasiënt. Die onafhanklike funksie van die verpleegkundige het te doen met verpleegdiagnose, behandeling en sorg en die wyse waarop sy haar pligte uitvoer en daarvoor verantwoordelikheid aanvaar.

Hierdie drieledige aard van die verpleegkundige se praktyk blyk reg deur die hele geskiedenis van die beroep.

\section{Laws were made that the stronger might not In all things have his way - Inde datae leges ne firmior omnia posset. Ovid. Fastr BK III I:279}

\section{INTRODUCTION}

In general, contemporary nursing literature from Western countries does not take a bold stand on the very controversial issue of the dependent and independent functions of the nurse practitioner. The authors write as if they are skating on very thin ice. Text books on nursing imply a great deal about the practice potential of nurses but ever and anon there is a subtle reversion to the concept that nursing has certain dependent functions, meaning functions that require a doctor's authorisation, and certain independent functions that are carried out on the nurse's own initiative, and responsibility. In general the majority of authors consulted appear to

This paper was presented at the 1st International Congress on Nursing Law and Ethics which took place in Jerusalem, Israel, June 13-17, 1982, and will appear in Book of Abstracts of the Congress which is at present in print and will be available shortly. subscribe to the concept postulated by Sarney when he says $A$ good nursing practice act will separate the independent functions (what nurse can do on her own) from the dependent functions (what she can do only under the direction of a doctor) (Sarney $1968: 18$ ).

The author questions this standpoint. We are living in an era of multi-disciplinary teamwork in the health field. In this team the patient is the leader of the team, not the doctor, although the doctor has certain specific levels of expertise that other members of the team do not have and in consequence makes the major diagnostic and therapeutic decisions. These decisions have largely to be implemented by other members of the health team. In this sense he then assumes direction of the total health care programme. Yet, in South Africa at least there is no law that says he is the leader, for chiropractors, psychologists, osteopaths, nurses and midwives all have legal right of practice. All these professionals may call him in to share the decision-making process, treatment and care of their patient. In some cases he may refuse to do so.

\section{THE QUESTION OF THE DE- PENDENT, INDEPENDENT AND INTERDEPENDENT FUNCTIONS OF THE NURSE}

It is precisely this position that raises the question of the dependent function of the nurse being one that is dependent on the doctor.

I believe that the functions of the nurse should be described as dependent, interdependent and independent with a shift in the traditional meaning of the dependent function.

\section{Dependent functlon}

The dependent function of the nurse is based on the law which authorises her practice, as well as on common law and relevant statutory laws. It is not based on that which the doctor prescribes, re- 
quests or directs for the patient. In accepting such direction or prescription the registered nurse acts as a professional person and is responsible and accountable for her own acts and omissions.

Without the observance of the provisions of the nurse practice act, she becomes criminally liable and without the observance of other health related legislation she may become civilly or criminally liable. The law is the system of rules that provides order in professional practice. It is the law, and only the law, that authorises her professional acts. She is dependent on the law for every aspect of her professional role and function. It must be emphasised that the locus of the dependent function of the nurse is, and remains, the law empowering her to practise. This includes the regulations made by the subsidiary legislative authority, namely the professional registration and controlling authority - the South African Nursing Council. It further includes decisions given by the courts anent the interpretation of such laws.

\section{Interdependent function}

The interdependent function relates to the inter-relationship of the nurse with the patient and with other members of the health team. In particular it relates to the interdependence of nursing and medicine. The nurse, whether as institutional practitioner or as private contractor, is not the servant or subordinate of the doctor. She is a registered nurse practitioner, entirely responsible and accountable for her own acts and omissions to the registration authority, the South African Nursing Council, and in the broader sense, to the courts. Where she accepts a prescription, request or direction for treatment of a patient from a doctor, she does so as an independent practitioner on behalf of her patient and as a shared responsibility with the doctor. She acts in the interests of her patient and in so doing has a joint responsibility with the doctor for ensuring that the patient is receiving the prescribed diagnostic and therapeutic care as well as the relevant nursing care. In other words, the patient is her patient as much as he is the patient of the doctor. She cannot distance herself from this elementary fact. Doctor and nurse have an interdependent and reciprocal responsibility. Neither can provide all the health care the patient needs. It is a joint as well as a broader team effort. In this respect a very substantial element of co-ordination of team activities is done by the nurse in the interest of the patient. The interplay of activities between doctor and nurse epitomises the interdependence of their functions.

The interdependent function is clearly recognised in the various health professional registration acts and in the regulations made thereunder. It is interesting to note that in South Africa, interprofessional co-operation is limited to those professions that are duly registered or enrolled under Act of Parliament, that is those that are dependent on legislation for their practice. Within these parameters all participants in any patient care situation have mutually interdependent, but also independent functions. Throughout such interdependent action the nurse remains responsible and accountable for the professional acts of commission or omission.

\section{Independent function}

The independent function of the nurse has two dimensions. One dimension relates to all those aspects inherent in nursing diagnosis, treatment and care which are the normal prerogatives of the nurse. The other dimension is concerned with the manner in which she carries out any of her duties as a registered nurse, whether this be an independent or interdependent function. Whatever she does, she does on her own responsibility and accountability for in law she is personally liable for her acts of omission or commission. She and she alone remains accountable for her actions. Only she can decide whether she is legally able, or knowledgeable and competent enough, to accept a specific prescription or direction from a doctor, or is able to participate in the care provided by other members of the health care team. Once she has indicated acceptance she has made an independent decision and accepts full responsibility and accountability for her decision and actions.

Even her decision to observe the provisions of the nurse practice or related laws is an independent function for which she is personally responsible and accountable. It is important to note that neither the nurse, nor the doctor, nor any other member of the health team is an autonomous practitioner, for such a practitioner does not exist. All the members of the multi-disciplinary health team are responsible and accountable to the patient, the registration authority and the law of the land, which is the vigilant sentry before the door of everyone's professional life. All are accountable, and if one is accountable one cannot be autonomous, be one doctor, nurse, psychologist, social worker, physiotherapist, or any other member of the health team.

The nurse is solely responsible and accountable for her own practice whether this be in a fee-for-service situation or in a salaried situation where she has to accept responsibility for a number of patients. This is the basis of her professional practice in South Africa. Her independent function supersedes and indeed pervades her interdependent function. (South African Nursing Council Regulations, 1950)

From where does she derive this authority, this delineation of function? These three functions are squarely based on the law governing the practice of medicine and of nursing in South Africa and on legal decisions which have been given by the courts in law suits involving patients, doctors and nurses (Nathan 1957 p.61-101). Without such laws and legal decisions professional practice for all health professions would be chaotic. These laws are not a restriction upon the freedom of a professional, but a gateway to greater freedom for they establish certain rules that, the health practitioner may not transgress. These laws are made to free the professional, not to bind him, by telling him what he may do without transgressing on the equal liberty of other health professionals. 


\section{EXCLUSIVE RIGHT OF THE DOCTOR TO CLINICAL RE- SPONSIBILITY NOT ESTABLISHED IN LAW}

In South Africa, the Medical, Dental and Supplementary Health Service Professions Act 56 of 1974, as amended, governs the practice of medicine, dentistry, psychology and the supplementary health professions. Nursing, midwifery, pharmacy and chiropractic are not supplementary health professions. They are professions in their own right with their own practice acts. The Medical, Dental and Supplementary Health Professions Act prohibits any person who is not registered as a doctor, excluding persons registered under the Nursing Act and the Chiropractors Act, performing any act whatsoever having as its object the diagnosing, treating or preventing of any physical (including mental) defect, illness or deficiency in any person, including the giving of advice in regard to such defects, illnesses or deficiencies, or the prescribing or providing of medicine in connection with such defects, illnesses or deficiencies. (The Medical, Dental and Supplementary Health Professions Act 56 of 1974, Section 36.)

The Nursing Act also sets out under what circumstances, which are not emergency situations, nurses may be authorised by the Nursing Council to prescribe and provide scheduled medicines or to prescribe and provide medical treatment (as distinct from nursing treatment and care and as distinct from emergency health care) in the absence of a doctor or pharmacist. (Nursing Act 50 of 1978 as amended by Act 71 of 1981, Section 38 s.) The extensive grey areas between nursing and medicine where there is overlapping of the functions which can be performed with varying levels of knowledge and skill is thus duly recognised in law.

In a free enterprise health care system such as pertains in South Africa, the law and its regulations impose certain limits of action upon both doctor and nurse. Both may charge fees for patient care, but neither practitioner is free to charge the patient the maximum fees that he/she may wish to impose. The maximum fees chargeable in private practice are prescribed by the medical and nursing councils respectively. Neither may such practitioners enter into an agreement whereby the patient undertakes to assume responsibility for negligent treatment. (Strauss \& Strydom, 1967: 317.) All registered health professionals, including the doctor and the nurse, are not only dependent on the laws and regulations authorising their practice but within the ambit of their professional code of ethics cannot perform professional acts for which they are not adequately trained and/or insufficiently experienced except in an emergency. (Strauss, 1981: 4.) Common law is explicit in this regard, namely that $a$ practitioner who performs such acts may be held liable for damage or injury suffered by the patient in consequence thereof on the basis of negligence. (Strauss, 1981: 4.) This is a very powerful inducive to responsible action in which the practitioner has the independent function of personal responsibility and accountability.

Nothing in an agreement between doctor and patient requires the doctor to provide all the care the patient needs, for clearly in the multi-disciplinary team context, and in the very nature of modern total care, this is unthinkable. The doctor cannot and does not have sole clinical responsibility for the patient.

In a country with a well regulated health practice system some authority has to authorise practice and assign responsibilities. This is done by Parliament which enacts legislation for the regulation of the various professions in the interests of the public, (Strauss \& Strydom, 1967: 9) and on this legislation the professional is dependent.

\section{NURSES MUST TAKE A STAND ON THE MEANING OF THE DEPENDENT, INDEPEN- DENT AND INTERDEPEN- DENT FUNCTIONS}

For most of nursing's long history there is evidence that nursing has always had this three dimensional basis of practice. An attempt is made to sketch this assertion.

\section{Preliterate soclety}

In preliterate societies the locus of authority for any action relating to a member of the family rested with the head of the family and through him to the extended family, the clan or the tribe. The dependent function stemmed from this, namely the law of the head of the family. The independent function related to the care provided by the responsible family member who had to exercise great responsibility and accountability in carrying out such care. The interdependent function was very much to the fore, for within the particular social pattern the provider of care had very definite interdependent responsibilities with other members of the extended family or clan and with the traditional healer.

\section{Early Hebrew society}

These selfsame functions are epitomised in the early Hebrew period by the legal and ethical stance adopted by the midwives Siphra and Pua who disregarded the injunction of the Pharaoh that they had to kill all the newborn male infants born to the people of Israel. Awareness of the temporal laws of Egypt, but utter obedience to the laws of Jehovah, close interdependence with the leaders and teachers of their people and independent action by the midwives characterised the actions of these midwives. (Exodus 1: 15-21)

\section{The Hippocratic period}

We see a new development in the Hippocratic period where there appears to be a shift away from this approach. Shryock quotes a translation which indicates the need for and the position of the nurse with reference to instruments used in an operation. But if another gives them he must be ready a little before hand and do as you direct (Shryock, 1959: 53). Clearly a dependent position on the physician. It has not been possible to trace what the measure of responsibility and accountability was in such cases. It appears that the physician assumed an all powerful role. These deductions may be wrong. 
The monastic, crusader, military and secular nursing orders were all dependent for the provision of health care on Canon Law, or the laws of the church and the rules of the respective Orders approved by the church. These Orders all acted on the Christian ethic as exemplified in Christ's teaching that identified the love of one's neighbours with the love of God in his promise that inasmuch as ye have done unto the least of these my brethren, ye have done it unto me (Matthew 25:40). With the words I was sick and ye visited me, nursing was lifted to a plane of moral obligation, and an ethical tradition was born. The locus of authority was Canon Law, on which the dependent function of the nurse was based. A very strict interdependent function existed with other members of the religious order who shared patient care, and with the priests for spiritual care, but within these parameters the provider of nursing care had the independent function of diagnosing, prescribing and providing treatment and care, and of ensuring that her interdependent functions were carried out within the dictates of the policy of mother church. For all this she was held responsible and accountable to the superiors of the order and to the mother church. The above pattern also flourished in feudal times when the lady of the manor provided care within identical parameters.

Throughout the long history of the Christian church, the men and women who carried the Christian faith and Westernised healing services to all corners of the earth provided nursing within these parameters. Common law apparently made little impact on their practice. Canon law was the foundation on which they built - it was their sole source of authority. It was the 19th and 20th Century developments that highlighted the common law components of practice and brought statutory foundations for the practice of nursing and medicine.

In all these periods of nursing history, except perhaps in the Hippocratic period, accountability was a well entrenched concept. Sanctions of some kind or other always existed and could be imposed on those who failed in their accountability.

\section{The Dark Ages in health care}

The eminently logical and orderly system of health care provided under Canon Law fell into disuse at the time of the Reformation, when the care of patients was wrested from the hands of the great religious orders. Felons, indigents, drunken slatterns, even other patients provided such care as existed in the Poor Law institutions. Chaos in the institutionalised care of the sick threw the functions of the provider of nursing care into disarray, with no clear distinction between the functions of a nurse and the functions of the lowest grade of domestic servant.

\section{The Nightingale era}

When Florence Nightingale came on the scene in her struggle to reorganise hospitals and health care systems, and working as she did within a military system, she totally sacrificed the potential legal functions of the nurse to the orders of the doctor, that is to the military orders of a military officer. She required total dependence and absolute obedience to the doctor within a military hierarchial system. Moreover she required the submissiveness akin to that of the religious sister as well as the unquestionable obedience of a person in the military system who was subordinate to the officer class. To enforce respectability in nursing she had to require rigid observance to military discipline and orders. In the process she undermined the professional development of nursing even after legislation was enacted for registration of nurses and the nurse was given a legal role of her own. She started the concept of the nurse having a function dependent on the doctor. With the wisdom of hindsight, we lay this accusation at her door, forgetting that we who have lived in an era of professional registration of nurses, have happily perpetuated this myth. Our sin is the greater!
The pernicious concept of the function of the nurse being dependent on the orders of the doctor was carried to every part of the world where the Nightingale system penetrated. By five words - the orders of the doctor - uttered in a male dominated, Victorian, military milieu, nursing practice was denied its legitimate professional rights and responsibilities for many decades. In some parts of the world this concept still persists.

\section{THE NURSE THE TOOL FOR REORGANISATION OF \\ HOSPITALS}

In the struggle to reorganise hospitals and to keep the costs of this as low as possible, the nurse was made the tool for such reorganisation. Her own professional rights and responsibilities were ruthlessly denied her, even after legislation was enacted enabling her to be a professional practitioner in her own right with only one source for the dependent dimension of her practice - the law.

The training system ensured that a docile, brainwashed, manageable person, ill-equipped to fight for her professional rights, provided the cheap, yet disciplined and well skilled service that enabled hospitals to exist, medical schools to flourish, and medical practitioners to grow prosperous on the sweated labour of the nurse. The myth that the nurse was dependent on the medical practitioner for the authorisation of her practice, and that she was subservient to him, persists despite legislation to the contrary. This approach resulted in the nurse seeking power and authority in the administrative system of the health service. She relegated the all important clinical function which is basic to the authorisation for practice, to a secondary place. Evidence of this abounds around the world. Until the nurse recognises the error in this approach she will not understand the three dimensional nature of her function and will not appreciate the vital importance of her dependent function that has its locus in the law. 
FIRST PROFESSIONAL

REGISTRATION OF NURSES LOCATED THE DEPENDENT FUNCTION OF THE NURSE IN THE LAW

The very first legislation in the world to recognise nursing as a profession and to register nurses, was enacted by the Parliament of the Cape Colony (now the Cape Province of South Africa) on 21 August, 1891. This Act, the Medical and Pharmacy Act No 34 of 1891, provided for the registration of nurses and midwives on the same register as medical practitioners, dentists, pharmacists and druggists. It provided such basic principles for the registration of a professional person as training, examination, certification, registration, disciplinary control, recognition of further study and qualification, protection of the rights of persons registered, as well as the protection of the public to be served. This law and its relevant regulations provided for the cancellation of certificates and the withdrawal of the right of practice for incompetence, negligence, acts of omission and commission, and conduct unbecoming to a professional person. All this required an independent function and accountability.

Despite the fact that the law clearly delineated the nurse as a separate category of practitioner, re- sponsible for her own conduct and practice, the myth persisted. The author believes that the myth persisted for an ethical reason that had a very heavy overlay of etiquette. The nurse makes a commitment to patient care that goes beyond her own feelings. She subscribes to both the negative apodosis of primum nocere - doing no harm to the patient, and the positive protasis ensuring benefit for the patient. These have their origins in the Hippocratic concept of being helpful and doing no harm. In the quasi-religious-quasi-military atmosphere of the re-organised hospital service the nurse was enjoined to observe the strict etiquette of acknowledging the seniority of the medical officer. In time she saw this as an ethical obligation, denying her legal dependent function and her own independent function in the process. Nevertheless in the de facto situation she adroitly exercised her independent function without raising any dust about it. It took several lawsuits in South Africa, as well as the establishment of the South African Nursing Council, through the enactment of the Nursing Act No 45 of 1944, to bring it home to the nurse that only the said Council, empowered by the law, can determine what her practice is, and that she is personally responsible and accountable for how she exercises her dependent, independent and interdependent functions. This is slowly being recognised by the doctor and the nurse, but such change is drawn out for it is part of the overall societal change in South Africa.

\section{REFERENCES AND GENERAL BIBLIOGRAPHY}

Andrews, W.A.; The doctor in history, lierature and folk lore Hull: W.A. Andrews Co. 1896 Reprinted by University Microfilms International Ann Arbor 1981.

Fenner, K.M.; Ethics and law in nursing van Nostrand Reinheld New York 1980

Mead, Hurd K.C.; $A$ history of women in medicine Haddam Press Connecticut 1937 Reprint B VI Longwood Press 1979

Nathan, The Rt Hon Lord Medical negligence Butterworth \& Co London 1957

Martin. A.J.; Duty of care Nursing Times September 9, 1976 p 1379.

Sarney, H.; The nurse and the law W.B. Saunders Philadelphia 1968.

Searle, C.; A socio-historical survey of nursing in South Africa, 1652 - 1960 Struik Cape Town 1965.

Searle, C.; The ward sister - some aspects of her role and function Curationis Vol 3 No 1 p 6 June 1980.

Shryock, R.H.; The history of nursing W.B. Saunders Philadelphia 1959.

Strauss, S.A.; Strydom, M.J.; Die Suid-Afrikaanse Geneeskundige Reg Van Schaik Publishers Pretoria 1967.

Strauss, S.A.; Legal handbook for nurses and health personnel King Edward VII Trust Cape Town 1981 th Ed

Thompson, J.B ; Thompson, H.O.; Eshics in nursing MacMillan 1981 New York

Professlonal legisiation in South Africa

- The Medical and Pharmacy Act, 34 of 1891

- The Nursing Act, 45 of 1944

The Nursing Act, 50 of 1978 as amended by Act 71 of 1981

South African Nursing Council Regulations - Acts and omissions of registered nurses. G N 1650 of 14 September 1973 as amended by $G N 481$ of March $1978: 1$

- The Medical, Dental and Supplementary Health Service Professions Act, 50 of 1974 as amended

- The Chiropractors Act, 76 of 1971

- The Homeopaths, Naturopoths, Osteopaths and Herbolist Act, 52 of 1974.

- The Pharmacy Act, 53 of 1974

- Miscellaneous Acts relating to the proviston and control of health services, medicine and drugs, abuse of dependence producing substances, hazardous substances, organ and tissue transplants, birth, marriages and deaths, abortion and sterilisation acts.

\section{Completed Research Voltooide Navorsing}

\section{DIE BENUTTING VAN DIE GE- REGISTREERDE VROEDVROU IN DIE REPUBLIEK VAN SUID-AFRIKA}

\author{
Catharina Fiorina van Niekerk \\ Magister Curationis (Verplegingsonderwys) \\ Departement Verpleegkunde, Universiteit van Pre- \\ toria
}

Hierdie ondersoek na die werklike omvang van die geregistreerde vroedvrou se rol bevestig talle verwysings na haar omvattende bydrae in die Republiek van SuidAfrika. Geregistreerde vroedvroue is inderdaat kernpersoneel in die voorsiening van 'n omvattende gesondheidsdiens.
As onontbeerlike lid van die gesondheidspan bevorder sy bio-psigo-sosiale welsyn van moeder en baba, die hart van die volk.

As professionele praktisyn, wanneer nodig, staan sy in vir afwesige gesondheidspanlede. Sy aanvaar aanspreeklikheid vir sowel selfopgelegde as voorgeskrewe handelinge.

Die geregistreerde vroedvrou, meesal omvattend voorberei vir haar optrede, erken nogtans 'n behoefte aan voortgesette onderwys. Vir die uitvoering van gespesialiseerde verloskundige verpleeghandelinge is nabasiese registreerbare onderwys ' $n$ voorvereiste.

Die kompleksiteit en omvang van verloskundige verpleegpraktyk vereis bykomende magtigende gesondheidswetgewing as die doelwit van bestaande wetgewing - voorsiening van omvattende gesondheidsorg vir die gemeenskap - bereikbaar moet bly. 